\title{
A Hybrid Data-Driven Machine Learning Technique for Evapotranspiration Modeling in Various Climates
}

\author{
Mohammad Valipour ${ }^{1, *}$, Mohammad Ali Gholami Sefidkouhi ${ }^{2}$, Mahmoud Raeini-Sarjaz ${ }^{2}$ and \\ Sandra M. Guzman ${ }^{1}$ (D) \\ 1 Department of Agricultural and Biological Engineering, Indian River Research and Education Center, \\ University of Florida, Fort Pierce, FL 34945, USA; sandra.guzmangut@ufl.edu \\ 2 Department of Water Engineering, Sari Agricultural Sciences and Natural Resources University, Sari, Iran; \\ magholamis@yahoo.com (M.A.G.S.); raeini@yahoo.com (M.R.-S.) \\ * Correspondence: mvalipour@ufl.edu
}

Received: 2 May 2019; Accepted: 1 June 2019; Published: 5 June 2019

check for updates

\begin{abstract}
In the current research, gene expression programming (GEP) was applied to model reference evapotranspiration (ETo) in 18 regions of Iran with limited meteorological data. Initially, a genetic algorithm (GA) was employed to detect the most important variables for estimating ETo among mean temperature (Tmean), maximum temperature (Tmax), minimum temperature (Tmin), relative humidity (RH), sunshine (n), and wind speed (WS). The results indicated that a coupled model containing the Tmean and WS can predict ETo accurately (RMSE $=0.3263 \mathrm{~mm} \mathrm{day}^{-1}$ ) for arid, semiarid, and Mediterranean climates. Therefore, this model was adjusted using the GEP for all 18 synoptic stations. Under very humid climates, it is recommended to use a temperature-based GEP model versus wind speed-based GEP model. The optimal and lowest performance of the GEP belonged to Shahrekord (SK), RMSE $=0.0650 \mathrm{~mm} \mathrm{day}^{-1}$, and Kerman (KE), RMSE $=0.4177 \mathrm{~mm}$ day $^{-1}$, respectively. This research shows that the GEP is a robust tool to model ETo in semiarid and Mediterranean climates $\left(\mathrm{R}^{2}>0.80\right)$. However, GEP is recommended to be used cautiously under very humid climates and some of arid regions $\left(\mathrm{R}^{2}<0.50\right)$ due to its poor performance under such extreme conditions.
\end{abstract}

Keywords: machine learning; crop water requirement; Iran; hydrological extremes; uncertainty; weather parameters

\section{Introduction}

Evaluation of reference evapotranspiration (ETo) plays an important and undeniable role in irrigation scheduling, drought analysis, climate change studies, water level balance, agricultural and forest meteorology, long-term decision-making in food and water security policies, and optimum allocation of water resources [1-3]. Although several methods have been developed to predict ETo throughout the world, there is a limited number of models to estimate ETo where meteorological data is restricted or insufficient [1,2].

A solution to deal with this limitation is to use data-driven machine learning techniques, particularly genetic approaches, including genetic algorithm (GA) and gene expression programming (GEP). One advantage of the GEP to estimate ETo was that, unlike the artificial neural networks (ANN) method, the GEP generated an explicit model structure that can be easily comprehended and adopted [3].

The GA and GEP methods have been developed in various aspects of water resources such as streamflow forecasting [4], rainfall-runoff modeling [5-8], modeling transport streams with suspended 
sediment [9], predicting velocity in compound channels [10], characterizing risks in water supply systems [11], and modeling evaporation [12].

Although the GEP has been developed in water resources studies, the application of this technique for ETo modeling is limited. Some of the successful applications of the GEP to estimate ETo can be listed as follows.

Parasuraman et al. [3] modeled ETo using only ground temperature and net radiation. Irmak and Kamble [13] investigated evapotranspiration data assimilation with the GA and soil, water, atmosphere, and plant (SWAP) model for on-demand irrigation. The data assimilation methodology obtained from the present research can be considered a practical tool at the field scale for scheduling the irrigation estimated by remote sensing-based evapotranspiration. The results showed that the GA was effectively able to determine the terms included in the fitness function, and parameters were predicted reasonably, especially if only four variables were included. Traore and Guven [14] developed regional-specific numerical models of ETo using the GEP in Sahel. Statistically, the GEP was an effectual modeling tool for the successful computation of ETo under the study area. The results indicated that, using the GEP model, it would be possible to formulate an accurate and applicable numerical equation for each region by irrigation systems for the manual computation of ETo under the study area, where sufficient meteorological variable is often missing. Shiri [15] claimed that GEP outperforms empirical model to calculate ETo in hyper arid regions over Iran. Traore et al. [16] found that GEP is a robust tool to model ETo in in Jiangsu province, China. Mattar [17] demonstrated that GEP is a more accurate method than empirical equations to estimate ETo in Egypt.

Machine learning methods are needed in data sparse regions because Penman-Monteith equation requires a lot of data input, and many places do not have such data. Therefore, achieving similar results with fewer input data is desirable.

In addition, some studies reported greater accuracy of the GA/GEP rather than the ANN [18-21], Support Vector Regression (SVR) [20,22], Adaptive Neuro-Fuzzy Inference System (ANFIS) [1,2,23], and empirical models [2,24].

According to the literature review there are some investigations for which the superiority of the GA and GEP over other techniques such as the ANN, LP, ANFIS, and regression models have been reported. However, genetic approaches have not been simultaneously assessed under various climates. In addition, in most of previous studies, these methods were employed with many input data to estimate ETo. In different parts of the world, there is insufficient meteorological data due to the lack of synoptic stations or other limitations. Therefore, the current research seeks to evaluate ETo in four different climates in Iran to recognize the parameters with the most significant roles in ETo.

\section{Materials and Methods}

\subsection{Designing Structure of Genetic Algorithm (GA) for the Current Research}

In most of the previous investigations [1,2], a power function is presented as the optimal model to estimate ETo after modifying or calibrating the empirical models. Therefore, in the present research, various functions of the mean temperature (Tmean), maximum temperature (Tmax), minimum temperature (Tmin), relative humidity (RH), wind speed (WS), and sunshine (n) were defined and then combined by using summation and multiplying functions. The goal is to minimize the difference between the current functions with the FAO-Penman-Monteith (FPM) (Table 1). 
Table 1. Structure of genetic algorithm (GA) designed in this study.

\begin{tabular}{cc}
\hline Base & Formula \\
\hline Mean Temperature & $E T o=a_{1}\left(T_{\text {mean }}\right)^{a_{2}}+a_{3}$ \\
Differential Temperature & $E T o=b_{1}\left(T_{\max }-T_{\min }\right)^{b_{2}}+b_{3}$ \\
Relative Humidity & $E T o=c_{1}(R H)^{c_{2}}+c_{3}$ \\
Wind Speed & $E T o=e_{1}(W S)^{e_{2}}+e_{3}$ \\
Solar Radiation & $E T o=f_{1}(n)^{f_{2}}+f_{3}$ \\
Total (Summation) & $(E T o)_{G A}=\sum_{i=1}^{5} E T o_{i}$ \\
Total (Multiplying) & $(E T o)_{G A}=\prod_{i=1}^{5} E_{i}$ \\
Goal Function & Minimize $\left[(E T o)_{G A}-(E T o)_{F P M}\right]$ \\
\hline
\end{tabular}

In the next step, a GA program was coded in MATLAB environment using the values shown in Table 2.

Table 2. Parameters of genetic algorithm (GA) coded in this study by using MATLAB environment.

\begin{tabular}{cccc}
\hline Value & Option & Value & Option \\
\hline $1.00 \mathrm{E}-06$ & TolFun & doubleVector & PopulationType \\
$1.00 \mathrm{E}-06$ & TolCon & {$[2 \times 1$ double $]$} & PopInitRange \\
10 & InitialPenalty & 20 & PopulationSize \\
100 & PenaltyFactor & 2 & EliteCount \\
1 & PlotInterval & 0.8 & CrossoverFraction \\
@gacreationuniform & CreationFcn & Forward & MigrationDirection \\
@fitscalingrank & FitnessScalingFcn & 20 & MigrationInterval \\
@selectionstochunif & SelectionFcn & 0.2 & MigrationFraction \\
@crossoverscattered & CrossoverFcn & 100 & Generations \\
$\{[$ @mutationgaussian ] [1] [1]\} & MutationFcn & Inf & TimeLimit \\
Final & Display & - Inf & FitnessLimit \\
Off & Vectorized & 50 & StallGenLimit \\
Never & UseParallel & Inf & StallTimeLimit \\
1.00E-06 & TolFun & doubleVector & PopulationType \\
1.00E-06 & TolCon & {$[2 \times 1$ double $]$} & PopInitRange \\
\hline
\end{tabular}

2.2. Parameters of Gene Expression Programming (GEP) Employed in the Current Research by Using GeneXpro Tools Version 5.0

Table 3 shows the values of each option employed to design the GEP structures by using GeneXpro Tools version 5.0.

As shown in Table 3, the population size of 500 is the same as most previous research.

However, different functions are employed to enhance the results and to reduce the uncertainty in the research, and the number of replication is increased (almost 217). As a result, the elapsed time to run the GEP can be prolonged. In addition, the ranking method showed better performance compared to Roulet's function (a fitness evaluation function). 
Table 3. Parameters of gene expression programming (GEP) employed in this study by using GeneXpro Tools version 5.0 .

\begin{tabular}{cc}
\hline Value & Option \\
\hline$+,-, \times, \div, \sqrt{ }, \sqrt[3]{ }, 4, \sin , \cos , \ln$, exp & Function set \\
500 & Population size \\
95 & Mutation frequency \\
50 & Crossover frequency \\
217 & Number of replication \\
30 & Block mutation rate \\
30 & Instruction mutation rate \\
40 & Instruction data mutation rate \\
95 & Homologous crossover \\
Ranking & Selection method \\
1 & Recombination rate \\
0.2 & Mutation rate \\
Generalize & Alternative method \\
Yes & Elitism \\
6 & Maximum level of tree \\
\hline
\end{tabular}

\subsection{Materials}

The monthly averages of meteorological data were collocated from the Islamic Republic of Iran Meteorological Organization (IRIMO). These data contain mean, minimum, and maximum daily air temperature $\left({ }^{\circ} \mathrm{C}\right)$, saturated vapor pressure deficit $(\mathrm{kPa})$, mean and minimum relative humidity $(\%)$, wind speed $\left(\mathrm{m} \mathrm{s}^{-1}\right)$ and direction, rainfall $\left(\mathrm{mm} \mathrm{month}{ }^{-1}\right)$, cloudy days, and sunshine $\left(\mathrm{hr} \mathrm{month}{ }^{-1}\right)$. Table 4 shows the position of all 18 synoptic stations and their climates. It should be noted that Iran is in an arid and semiarid zone in Persian Gulf region, and the major part of Iran has the same climate mentioned in Table 4. Figure 1 shows location of the weather station in Iran.

Table 4. Position and climate of the stations with length of collected data.

\begin{tabular}{cccccccc}
\hline $\begin{array}{c}\text { Station } \\
\text { Name }\end{array}$ & $\begin{array}{c}\text { ICAO } \\
\text { Code }\end{array}$ & $\begin{array}{c}\text { North } \\
\text { Latitude }\end{array}$ & $\begin{array}{c}\text { East } \\
\text { Longitude }\end{array}$ & $\begin{array}{c}\text { Altitude } \\
\text { (masl) }\end{array}$ & Start Year & End Year & Climate \\
\hline Ahvaz & 40811 & $31^{\circ} 20^{\prime}$ & $48^{\circ} 40^{\prime}$ & 22.5 & 1961 & 2010 & Arid \\
Arak & 40769 & $34^{\circ} 6^{\prime}$ & $49^{\circ} 46^{\prime}$ & 1708.0 & 1961 & 2010 & Semiarid \\
Bushehr & 40858 & $28^{\circ} 58^{\prime}$ & $50^{\circ} 49^{\prime}$ & 9.0 & 1961 & 2010 & Arid \\
Esfahan & 40800 & $32^{\circ} 37^{\prime}$ & $51^{\circ} 40^{\prime}$ & 1550.4 & 1961 & 2010 & Arid \\
Hamedan & 40768 & $34^{\circ} 52^{\prime}$ & $48^{\circ} 32^{\prime}$ & 1741.5 & 1961 & 2010 & Semiarid \\
Jiroft & 40866 & $28^{\circ} 35^{\prime}$ & $57^{\circ} 48^{\prime}$ & 601.0 & 1989 & 2009 & Arid \\
Kerman & 40841 & $30^{\circ} 15^{\prime}$ & $56^{\circ} 58^{\prime}$ & 1753.8 & 1961 & 2010 & Arid \\
Mashhad & 40745 & $36^{\circ} 16^{\prime}$ & $59^{\circ} 38^{\prime}$ & 999.2 & 1961 & 2010 & Semiarid \\
Moghan & 40700 & $39^{\circ} 39^{\prime}$ & $47^{\circ} 55^{\prime}$ & 31.9 & 1984 & 2010 & Semiarid \\
Qazvin & 40731 & $36^{\circ} 15^{\prime}$ & $50^{\circ} 3^{\prime}$ & 1279.2 & 1961 & 2010 & Semiarid \\
Rasht & 40719 & $37^{\circ} 19^{\prime}$ & $49^{\circ} 37^{\prime}$ & -8.6 & 1961 & 2010 & Very humid \\
Sanandaj & 40747 & $35^{\circ} 20^{\prime}$ & $47^{\circ} 0^{\prime}$ & 1373.4 & 1961 & 2010 & Mediteranean \\
Shahrekord & 40798 & $32^{\circ} 17^{\prime}$ & $50^{\circ} 51^{\prime}$ & 2048.9 & 1961 & 2010 & Semiarid \\
Shiraz & 40848 & $29^{\circ} 32^{\prime}$ & $52^{\circ} 36^{\prime}$ & 1484.0 & 1961 & 2010 & Semiarid \\
Tabriz & 40706 & $38^{\circ} 5^{\prime}$ & $46^{\circ} 17^{\prime}$ & 1361.0 & 1961 & 2010 & Semiarid \\
Urmia & 40712 & $37^{\circ} 40^{\prime}$ & $45^{\circ} 3^{\prime}$ & 1328.0 & 1961 & 2010 & Semiarid \\
Yazd & 40821 & $31^{\circ} 54^{\prime}$ & $54^{\circ} 17^{\prime}$ & 1237.2 & 1961 & 2010 & Arid \\
Zabol & 40829 & $31^{\circ} 2^{\prime}$ & $61^{\circ} 29^{\prime}$ & 489.2 & 1961 & 2010 & Arid \\
\hline
\end{tabular}




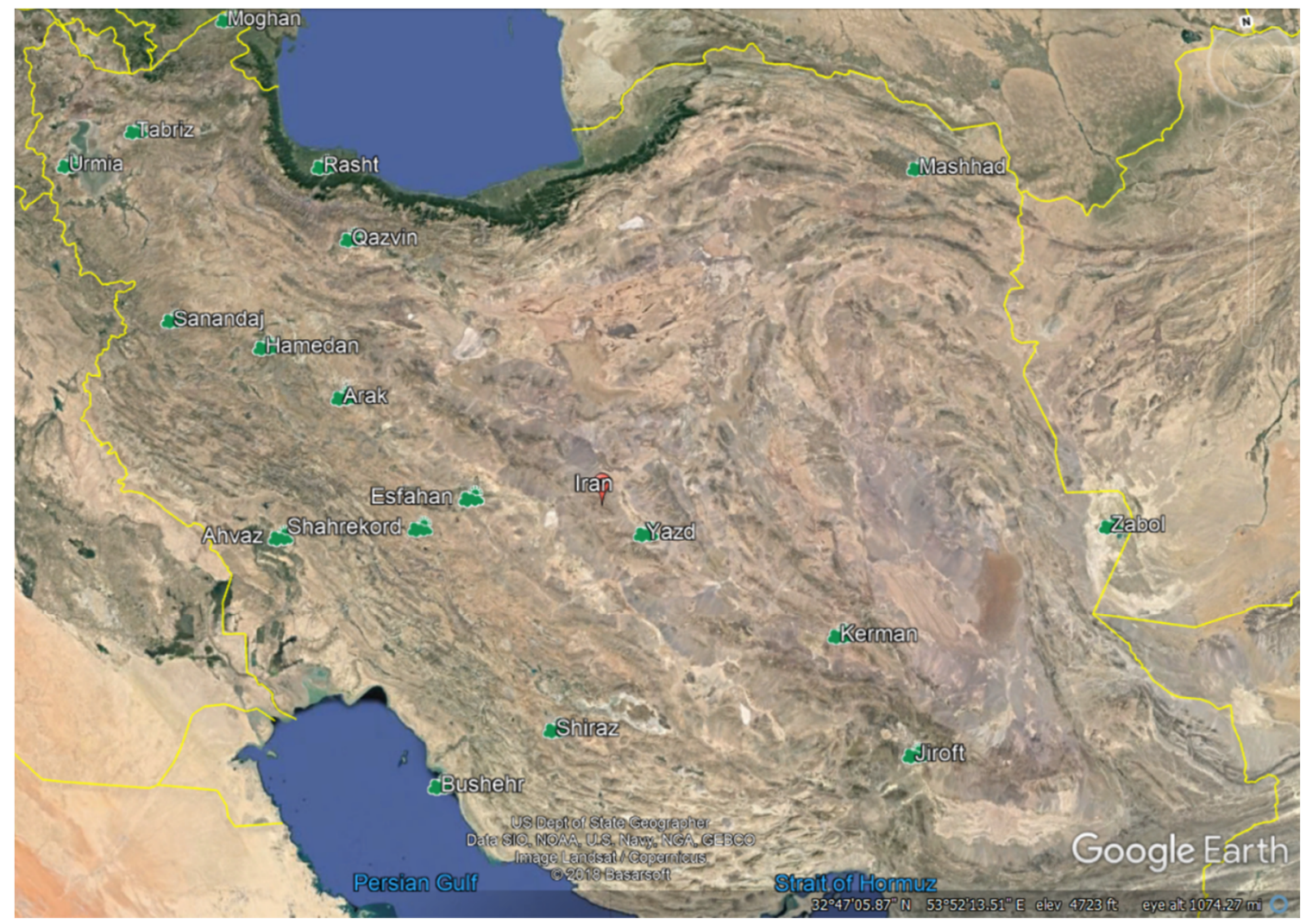

Figure 1. Location of the weather stations.

Among all stations, there is 50-year period information for 16 regions. The accuracy of the Food and Agricultural Organization of the United Nations (FAO)-Penman-Monteith (FPM) is confirmed for these regions by using lysimeter measurements and with respect to the previous investigations [25-34]. In addition, there are 27-year and 21-year period datasets for Moghan and Jiroft, respectively, which due to the availability of lysimeter data, confirms the accuracy of the FPM for these two regions; they were also added to other 16 regions (with 50-year data).

The authors have used the last five years as the testing period and the rest of the data as training period.

Table 5 shows the selected models with their references and parameters.

Table 5. Selected models to estimate reference evapotranspiration including their references, formulae, and parameters.

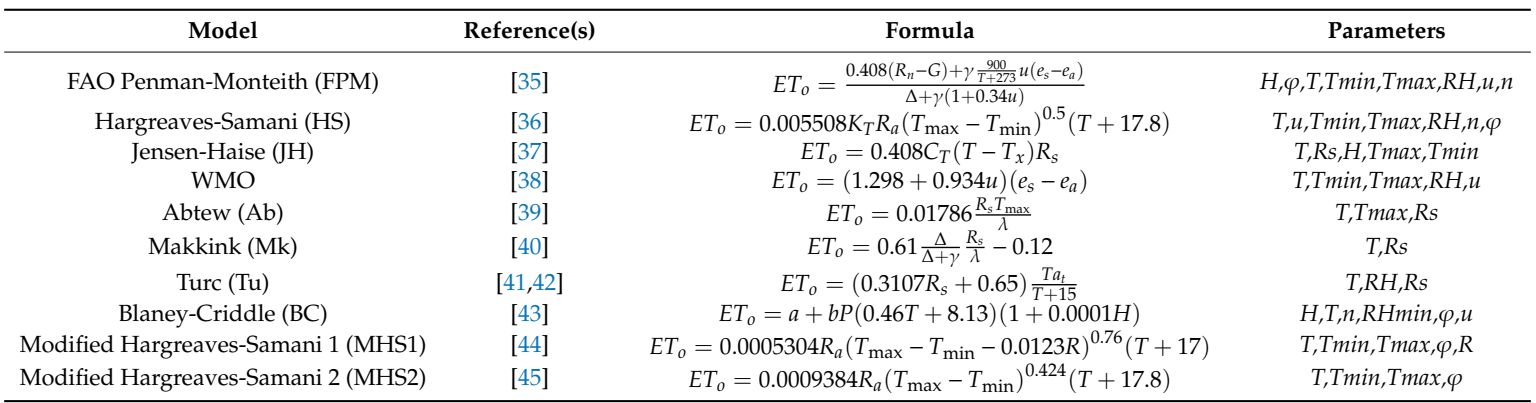

Among the numerous empirical methods to estimate ETo, nine models were selected that had the best performance under different climates on the basis of previous investigations [1,46-50], and the results were compared with the FPM. 
ETo is the reference crop evapotranspiration (mm/day), $R_{n}$ is the net radiation $\left(\mathrm{MJ} / \mathrm{m}^{2} /\right.$ day), $\mathrm{G}$ is the soil heat flux $\left(\mathrm{MJ} / \mathrm{m}^{2} /\right.$ day $), \gamma$ is the psychrometric constant $\left(\mathrm{kPa} /{ }^{\circ} \mathrm{C}\right), e_{s}$ is the saturation vapor pressure $(\mathrm{kPa}), e_{a}$ is the actual vapor pressure $(\mathrm{kPa}), \Delta$ is the slope of the saturation vapor pressure-temperature curve $\left(\mathrm{kPa} /{ }^{\circ} \mathrm{C}\right), T$ is the average daily air temperature $\left({ }^{\circ} \mathrm{C}\right), u$ is the mean daily wind speed at $2 \mathrm{~m}(\mathrm{~m} / \mathrm{s})$, $H$ is the elevation (m), $\varphi$ is the latitude (rad), $T_{\min }$ is the minimum air temperature $\left({ }^{\circ} \mathrm{C}\right), T_{\max }$ is the maximum air temperature $\left({ }^{\circ} \mathrm{C}\right), \mathrm{RH}$ is the average relative humidity $(\%), n$ is the actual duration of sunshine (hr), $R_{s}$ is the solar radiation $\left(\mathrm{MJ} / \mathrm{m}^{2} /\right.$ day), $R_{a}$ is the extraterrestrial radiation $\left(\mathrm{MJ} / \mathrm{m}^{2} / \mathrm{day}\right), \lambda$ is the latent heat of vaporization $(\mathrm{MJ} / \mathrm{kg})$, and $C_{T}, I, K_{T}, a, b, P, a_{t}$, and $T_{x}$ are empirical coefficients

Genetic algorithm (GA), genetic programming (GP), and gene expression programming (GEP) are different kinds of data-driven machine learning techniques to find an optimum solution for complex problems by artificial intelligence (AI). In a cell, the expression of the genetic information is an intricate procedure involving more than one hundred molecules. Two of the major players are DNA and proteins. DNA is the carrier of the genetic information and the proteins read and express the genetic information. GA employed biological evolution theory for computer applications (i.e., AI). In fact, GA is an oversimplification of biological evolution [51]. GP, introduced by [52,53], solves the problem of fixed length solutions (as stated for GA) by creating nonlinear entities. Each entity (parse tree) has a distinguished shape and size. GEP is the reliable modification of GP and GA, combining both the methodology of simple, linear chromosomes with fixed length (GA) and branched structures of various sizes and shapes (GP). GEP applies the same type of diagram representation of GP, however the entities (expression trees) evolved by GEP are the expression of a linear genome. The GEP is a constructive approach because the search operators of the GEP may constantly generate valid structures and are highly suited to genetic diversity. The GEP surpasses the old GP system for more than 100 times. In this study, the GA was employed to understand which parameters are more influential on the estimation accuracy of ETo. In addition, the GEP was used to model ETo considering the obtained results by the GA to achieve the maximum accuracy compared with the empirical methods. Therefore, a hybrid data-driven machine learning technique (considering both GA and GEP) was applied to model ETo in various climates.

To evaluate the accuracy of the models two indices were used as follows

$$
\begin{gathered}
R M S E=\sqrt{\frac{\sum_{i=1}^{n}\left(X_{i}-Y_{i}\right)^{2}}{N}} \\
R^{2}=\frac{\left[\sum_{i=1}^{n}\left(X_{i}-\bar{X}\right)\left(Y_{i}-\bar{Y}\right)\right]^{2}}{\sum_{i=1}^{n}\left(X_{i}-\bar{X}\right)^{2} \sum_{i=1}^{n}\left(Y_{i}-\bar{Y}\right)^{2}}
\end{gathered}
$$

where, $X_{i}$ and $Y_{i}$ are the $i$ th observed and estimated values, respectively; $\bar{X}$ and $\bar{Y}$ are the mean of $X_{i}$ and $Y_{i} ;$ and $N$ is the total numbers of data.

\section{Results}

\subsection{Performance of Genetic Algorithm (GA) for Different Parameters}

Table 6 shows that although GA8 (combination of all parameters) was obtained with the highest accuracy $\left(\mathrm{RMSE}=0.3030 \mathrm{~mm} \mathrm{day}^{-1}\right.$ ) in Iran (average), it requires four parameters: Tmean, $\mathrm{RH}$, WS, and $n$. On the other hand, GA5 is also obtained, which is approximately equal to GA8 $\left(\right.$ RMSE $=0.3263 \mathrm{~mm} \mathrm{day}^{-1}$ ) with less input data (only Tmean and WS). Meanwhile, GA5 estimated ETo throughout Iran with more accuracy than GA2, GA3, and GA4. This means that the WS was introduced as the most important factor (after Tmean) to control the dynamics of ETo process throughout Iran. 
Table 6. Performance of genetic algorithm (GA) for different parameters.

\begin{tabular}{ccc}
\hline Code & Parameters & Root Mean Square Error (RMSE) (mm/day) \\
\hline GA1 & Tmean & 0.6823 \\
GA2 & Tmean,Tmin,Tmax & 0.5049 \\
GA3 & Tmean,RH & 0.5733 \\
GA4 & Tmean,n & 0.6250 \\
GA5 & Tmean,WS & 0.3263 \\
GA6 & Tmean,WS,RH & 0.3087 \\
GA7 & Tmean,WS,n & 0.3211 \\
GA8 & Tmean,WS,RH,n & 0.3030 \\
\hline
\end{tabular}

Table 6 reveals that a function of the Tmean and WS may predict ETo with acceptable accuracy. Therefore, this result is the basis for the development of the genetic models using the GEP. However, the Tmean is the first parameter to be measured in each station or region. Hence, the Tmean is considered as the input parameter in the entire GEP models in this study.

\subsection{Performance of Gene Expression Programming (GEP) for Mean Temperature (Tmean) as Input Data}

In the first step of the GEP-ETo-was estimated in all 18 stations using only the Tmean and then compared with the FPM (Table 7).

Table 7. Performance of gene expression programming (GEP) for mean temperature (Tmean) as input data.

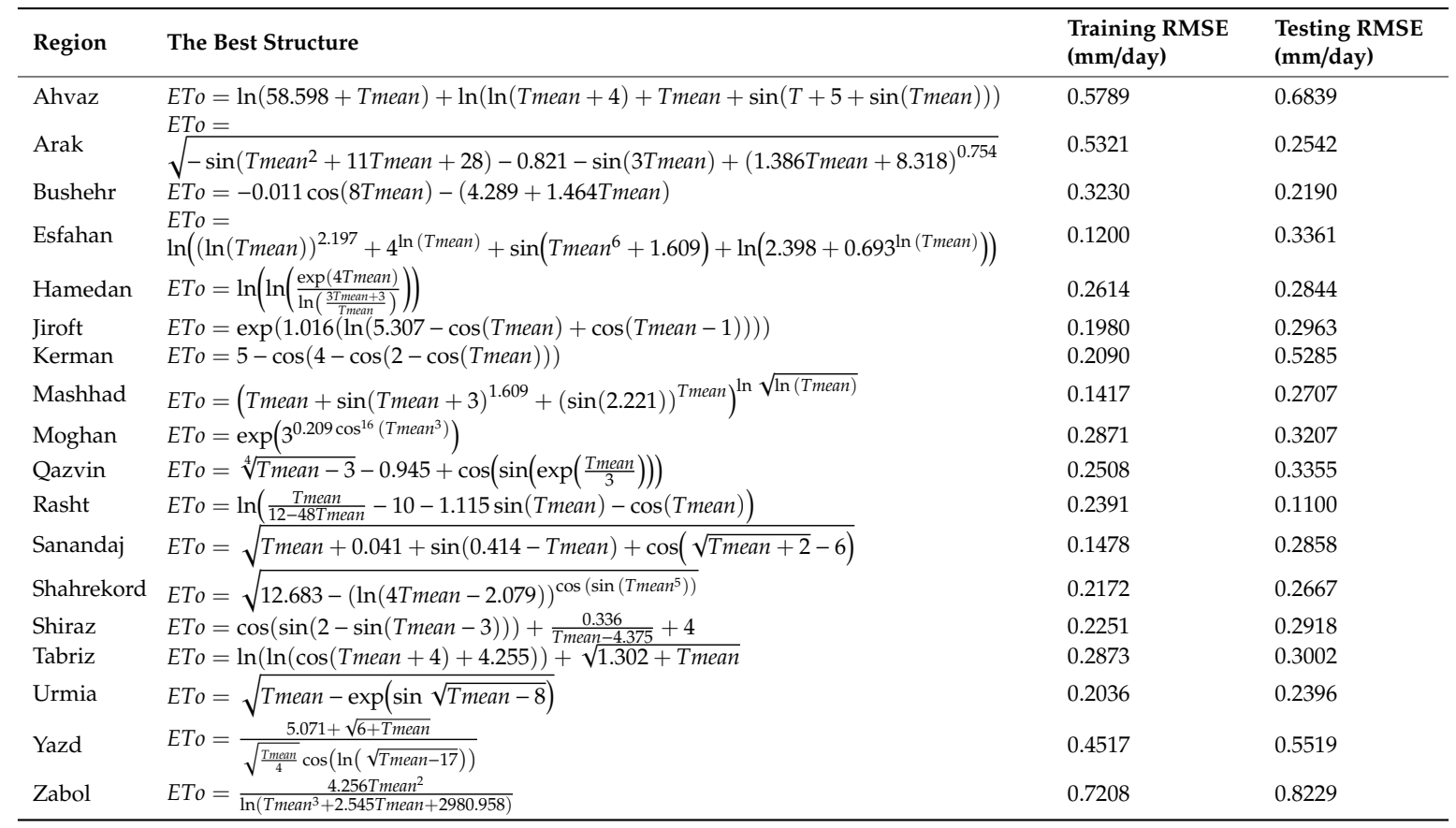

According to Table 7, the best performance of the GEP belongs to Rasht $\left(\right.$ RMSE $=0.1100 \mathrm{~mm} \mathrm{day}^{-1}$ ), while, the worst accuracy was reported for Zabol (RMSE $=0.8229 \mathrm{~mm} \mathrm{day}^{-1}$ ). In $56 \%$ of regions the GEP was obtained with a RMSE $<0.3000 \mathrm{~mm} \mathrm{day}^{-1}$. Furthermore, the natural logarithm (ln) function was employed more than sinus, cosines, and particularly exponential functions in the GEP structures. It means that we can expect to have logarithmic relationship between ETo and Tmean more than other kinds of functions. Moreover, plus and minus functions were used more than multiplication and specially division. 
3.3. Performance of Gene Expression Programming (GEP) for Mean Temperature (Tmean), Minimum Temperature (Tmin), and Maximum Temperature (Tmax) as Input Data

In the second step of the GEP, ETo was estimated in all 18 stations using the Tmean, Tmin, and Tmax was then compared with the FPM.

The results reveal that the best performance of the GEP belongs to Rasht (RMSE $=0.0884 \mathrm{~mm}$ day $^{-1}$ ), while the worst accuracy was reported for Zabol (RMSE $=0.8020 \mathrm{~mm} \mathrm{day}^{-1}$ ). In $61 \%$ of regions the GEP was obtained with a RMSE $<0.3000 \mathrm{~mm}^{-1 a y}{ }^{-1}$. Furthermore, sine and cosine functions were employed more than the natural logarithm (ln) and particularly exponential functions in the GEP structures. It means that we can expect to have periodic relationship between ETo and temperature more than other kinds of functions. Moreover, plus and minus functions were used more frequent than multiplication sign and particularly division sign. In all regions, the accuracy was improved compared to the GEP models based on the Tmean only.

\subsection{Performance of Gene Expression Programming (GEP) for Mean Temperature (Tmean) and Wind Speed (WS) as Input Data}

With respect to Table 6, WS was introduced as the most important factor to control the variations of ETo. Thus, in the third step of GEP, ETo was estimated in all 18 stations using the Tmean, and WS was then compared with the FPM (Table 8).

Table 8. Performance of gene expression programming (GEP) for mean temperature (Tmean) and wind speed (WS) as input data.

\begin{tabular}{|c|c|c|c|}
\hline Region & The Best Structure & $\begin{array}{l}\text { Training RMSE } \\
(\mathrm{mm} / \text { day })\end{array}$ & $\begin{array}{l}\text { Testing RMSE } \\
\text { (mm/day) }\end{array}$ \\
\hline Ahvaz & $E T o=3.189-\sqrt{W S-2+\text { Tmean }}+\sqrt{7+\text { Tmean }}$ & 0.2008 & 0.2128 \\
\hline Bushehr & $E T o=\ln (17.167$ WS +137.339$)-\frac{\exp \left(\cos \frac{1}{T \text { Tmean }}\right)}{\exp (\text { WS })+\cos (\text { WS } \times \text { Tmean })}-\frac{\exp \left(\cos \left(4-\text { Tmean }-\frac{W S}{8}\right)\right)}{W S+\exp (\ln (\text { WS })-0.8)}$ & 0.2018 & 0.1640 \\
\hline Esfahan & ETo $=\sqrt{\text { Tmean }}-\cos (W S)-0.006-\ln (\sqrt[4]{2-\cos (W S)})$ & 0.0835 & 0.0925 \\
\hline Jiroft & $E T o=W S+3.001-\frac{\exp \left(\sqrt{5^{\sin (\text { Tmean })}}\right)}{W S-13}$ & 0.1489 & 0.1401 \\
\hline Kerman & ETo $=\sqrt[4]{W S} \times \sqrt{\ln \left(W S+\frac{\text { Tmean }}{5}\right)} \times \ln \left(\right.$ Tmean $\left.+\frac{\sqrt{\text { Tmean }} \times \ln (W S)}{5}\right)$ & 0.2489 & 0.4177 \\
\hline Mashhad & $E T o=\exp \left(\frac{\text { Tmean }}{28}\right)+\ln \left(\frac{0.571(\text { Tmean }+W S)}{-\ln \left(\frac{W S}{7}\right)}\right)$ & 0.1107 & 0.1725 \\
\hline Sanandaj & $E T o=\sqrt{\text { Tmean } \times(\sqrt{W S}+0.745)}$ & 0.1740 & 0.1287 \\
\hline Shahrekord & ETo $=0.705 \times(\sqrt{(\text { Tmean }+7)}+\ln ($ WS $)-1-\cos (\ln (2+2$ Tmean $)))$ & 0.0583 & 0.0650 \\
\hline Shiraz & $E T o=\sqrt{\cos (2 W S+\text { Tmean }+26)+\cos (\text { Tmean }+5)+2 W S+\exp (\sqrt{W S+6})}$ & 0.1474 & 0.1403 \\
\hline Tabriz & $\begin{array}{l}E T o=\ln (\exp (\sin (\text { Tmean }))+6+\text { Tmean }+\sin (\sin (\text { Tmean })))-\frac{\sin (\text { Tmean })}{\ln (5+\text { WS })}+ \\
22025.465^{(\text {WS }-7)(\sin (\text { WS })+8)}\end{array}$ & 0.1487 & 0.1620 \\
\hline Urmia & ETo $=\cos \left(\frac{\text { WS }-6.135}{\text { Tmean }}\right)+\cos \left(\frac{12.96}{0.75+\text { WS }+ \text { Tmean }}\right)+\exp \left(\sqrt{\frac{\text { WS }}{5}}\right)-\frac{3}{\text { Tmean }}$ & 0.2049 & 0.1158 \\
\hline Yazd & $E T o=\sqrt[4]{\frac{\text { Tmean }^{2}-8 \text { Tmean }}{2}} \sqrt{(W S+0.008)}$ & 0.1790 & 0.1738 \\
\hline Zabol & $E T o=5.016-\frac{W S}{W S-1}-\frac{0.246-\frac{W S-2}{3}}{2.273-\cos (\text { Tmean })}$ & 0.3289 & 0.3612 \\
\hline
\end{tabular}

Table 8 represents that the best performance of the GEP belongs to Shahrekord $\left(\right.$ RMSE $=0.0650 \mathrm{~mm}$ day $\left.^{-1}\right)$, while the worst accuracy was reported for Kerman $\left(\right.$ RMSE $\left.=0.4177 \mathrm{~mm}_{\text {day }}{ }^{-1}\right)$. In $83 \%$ of regions the GEP resulted with a RMSE $<0.2000 \mathrm{~mm} \mathrm{day}^{-1}$. Furthermore, the natural logarithm (ln) function was employed more than sinus, cosines, and particularly exponential functions in the GEP structures. Moreover, plus and minus functions were used more than multiplication sign and specially division. In all regions (with the exception of Rasht), the accuracy was improved compared to the GEP models based on the Tmean, Tmin, and Tmax. 
Therefore, for Rasht, wind speed is not required. It may correspond to minimum diurnal temperature rate (DTR) in very humid regions compared to other climates (role of relative humidity and saturated vapor pressure). However, wind speed-based GEP models predicted ETo in arid, semiarid, and Mediterranean climates more accurate than the other models.

It should be noted that the arctan has not acceptable accuracy compared to other functions. In addition, the results represent that $\ln$ and exp functions have a better performance than sine and cosine functions. Therefore, in future investigations, we can more focus on other functions than arctan. In addition, we can expect to have logarithmic relationship between ETo and temperature/wind speed more than other kinds of functions.

The obtained results are comparable and sometimes better than those reported by Wang et al. [54]. They resulted RMSE between 0.222 to $0.555 \mathrm{~mm} \mathrm{day}^{-1}$. In addition, Mehdizadeh [55] reported RMSE for GEP models from 0.46 to $2.08 \mathrm{~mm}^{-1 a y}{ }^{-1}$.

3.5. Performance of Gene Expression Programming (GEP) for Mean Temperature (Tmean), Wind Speed (WS), and Relative Humidity (RH) as Input Data

The results of the GA revealed that use of the RH and $n$ do not increase accuracy of the GEP significantly (Table 6). This is also confirmed by the GEP.

According to the results, the best performance of the GEP was for Esfahan $\left(\right.$ RMSE $=0.0730 \mathrm{~mm} \mathrm{day}{ }^{-1}$ ), while the worst accuracy was reported for Kerman $\left(\right.$ RMSE $\left.=0.4252 \mathrm{~mm} \mathrm{day}^{-1}\right)$. In $89 \%$ of regions the GEP resulted with a RMSE $<0.2000 \mathrm{~mm} \mathrm{day}^{-1}$. Furthermore, sinus and cosines functions were employed more than the natural logarithm (ln) and particularly exponential functions in the GEP structures. Moreover, plus and minus functions were used more than multiplication sign and specially division.

A comparison of Table 8 indicates that adding the RH as input parameter not only did not increase the GEP's accuracy, but also led to the reduction in the accuracy relevant to $56 \%$ of the regions. In addition, the improvements are inconsiderable. It should be noted that the best structures of the GEP are not a function of the RH in $44 \%$ of the regions (Arak, Bushehr, Mashhad, Moghan, Qazvin, Sanandaj, Shahrekord, Shiraz, Tabriz, and Yazd). It is an important result and confirms that the Tmean and WS have more value to be used as input variable for the GEP compared to the RH.

\subsection{Accuracy of Empirical Models Against Gene Expression Programming (GEP)}

Figures 2 and 3 show that the best empirical models with respect to the smallest RMSE values for estimating ETo on a monthly scale lack a good performance at annual scale and this is alarming considering the importance of the agricultural water management to deal with water crisis in the world. However, the GEP may predict ETo in the most regions of Iran with considerable accuracy.

In arid regions (Figure 2), the best accuracy belongs to Esfahan $\left(R^{2}=0.9217\right)$ and the worst accuracy belongs to Kerman $\left(R^{2}=0.3636\right)$, due to poor performance of the GEP for peak events in this region. In the semiarid regions (Figure 3$)$, the best accuracy belongs to Shahrekord $\left(R^{2}=0.9403\right.$ ) and the worst accuracy belongs to Hamedan $\left(R^{2}=0.8049\right)$.

The obtained results are comparable and sometimes better than those reported by Wang et al. [54]. They resulted $R^{2}$ between 0.639 to 0.944 . In addition, Mehdizadeh [55] reported $R^{2}$ for GEP models from 0.084 to 0.969 . 

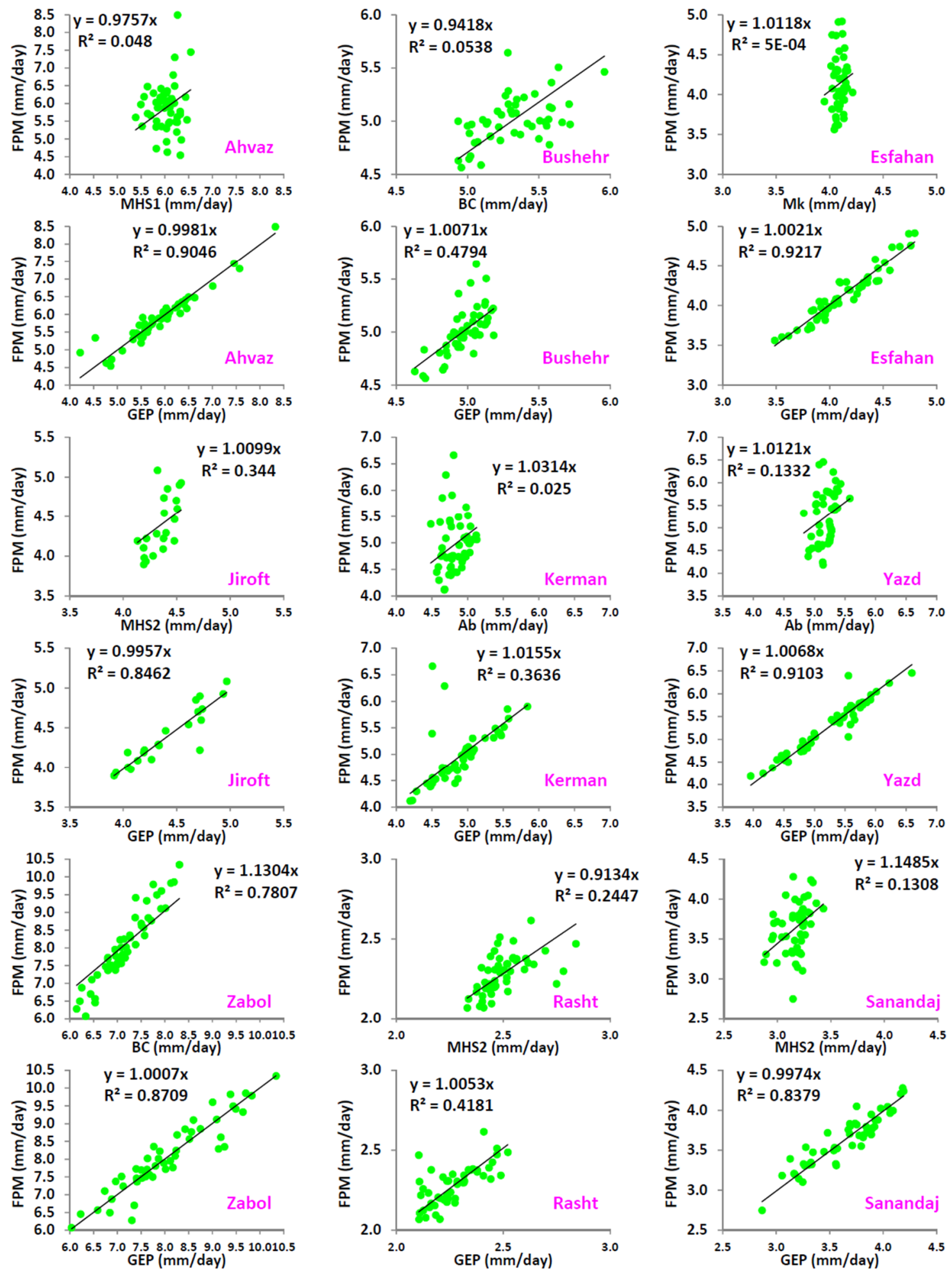

Figure 2. Accuracy of empirical models (annual mean ETo) against gene expression programming (GEP) in very humid (Rasht), Mediterranean (Sanandaj), and arid (other stations) climates. 

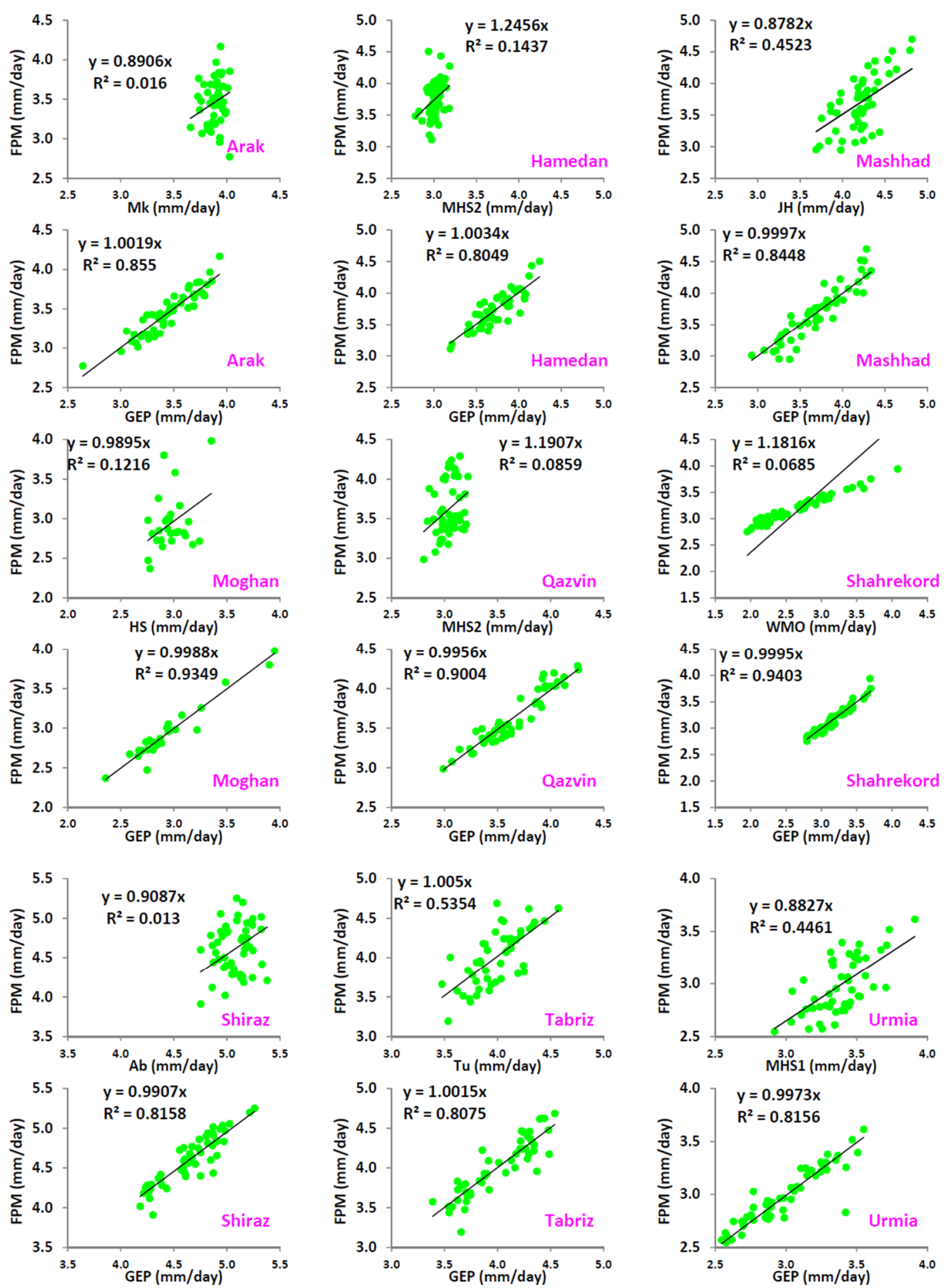

Figure 3. Accuracy of empirical models (annual mean ETo) against gene expression programming (GEP) in semiarid climates.

\section{Discussion}

The current research shows that the GEP is a robust tool to model ETo in semiarid and Mediterranean climates $\left(R^{2}>0.80\right)$. However, the use of the GEP should be recommended cautiously in Rasht, Bushehr, and Kerman $\left(R^{2}<0.50\right)$ due to its poor performance in extreme events of these areas. 
To enhance the accuracy of the GEP in extreme values, use of hybrid methods (coupling GEP with ANN, fuzzy logic, honey bee algorithm, etc.) can be recommended.

The results of this study has a potential to be compared with real data. However, reference evapotranspiration (ETo) refers to maximum evapotranspiration in the best growing conditions of a crop without any limitation (drought and salinity stresses). However, plant requirements evapotranspiration (actual evapotranspiration) refers to actual conditions of a crop in the field considering all limitations. Therefore, it is not acceptable to compare these to variables. To this end, a crop coefficient $(\mathrm{Kc})$ must be considered to characterize actual evapotranspiration (ETa); Eta $=\mathrm{Kc} \times$ ETo.

Considering complex processes of evapotranspiration, there are many difficulties to measure this parameter. Some of the methods for this end are lysimeter, remote sensing, eddy covariance, and Bowen ratio. Allen et al. [35] determined an accurate model (FPM) which has the highest adaptability with lysimeter measurements in all over the world. Therefore, in this study, such as most of previous investigations [13,18-20], the authors compared the outputs of the GEP with the FPM and the results (Figures 1 and 2) appear that the accuracy of the GEP has been improved compared to empirical models.

It should be noted that we cannot see similar results for the stations. In fact, all the results are completely independent of each other. This is in line with previous investigations [1,2].

It is notable that, in future research, the findings obtained from the GEP models in comparison to what is noted in the biological literature as affecting this process, should be checked to achieve a reliable result to recommend the GEP for other regions and research.

The GEP has worse performance over extreme conditions. The reason is related to the structure of GEP models. In this study, the authors focused on the models in which we need one or two weather parameters (mean temperature and mean wind speed) to estimate ETo. However, in extreme conditions, sometimes other variables, like maximum and minimum temperatures, maximum wind speed, rainfall, minimum humidity, solar radiation, and vapor pressure deficit, are also important. Therefore, if we are looking to increase the accuracy of GEP model we should consider more variables. However, in many regions we have no access to all of weather parameters to apply them to support GEP models to estimate ETo.

The next step of this study is to train the GA/GEP using ETo calculated at one site with all the meteorological variables available. Then, use the resulting functions to estimate ETo at a site where there are insufficient meteorological variables. Indeed, if we do have enough meteorological information to calculate ETo, we can then train the GA/GEP on fewer input variables.

\section{Conclusions}

In this study, the capability of both GA and GEP was assessed using 50-year time series data under 18 regions in Iran with arid, semiarid, very humid, and Mediterranean climates. The GA suggested that use of a double-parameter basis including the Tmean and WS may predict ETo with good accuracy in arid, semiarid, and Mediterranean regions. However, in very humid regions, temperature-based models (Tmean, Tmax, and Tmin) are better alternatives to reduce uncertainty. Finally, the GEP is recommended to evaluate the annual dynamics of ETo process in arid, semiarid, and Mediterranean climates with reliable accuracy under conditions where meteorological information is limited. In this study, we represented the best structures of GEP models. In future research, when a researcher or expert is going to use an accurate model based on this study, $\mathrm{s} /$ he may employ the best structures of GEP whose have been considered for his/her climate region.

Author Contributions: M.V. conceived and designed the study, performed the models, and wrote the manuscript. M.A.G.S. and M.R.-S. supervised the study. S.M.G. reviewed the manuscript.

Funding: This research received no external funding.

Conflicts of Interest: The authors declare no conflict of interest. 


\section{References}

1. Shiri, J.; Sadraddin, A.A.; Nazemi, A.H.; Kisi, O.; Landeras, G.; Fard, A.F.; Marti, P. Generalizability of gene expression programming-based approaches for estimating daily reference evapotranspiration in coastal stations of Iran. J. Hydrol. 2014, 508, 1-11. [CrossRef]

2. Shiri, J.; Kisi, O.; Landeras, G.; Lopez, J.J.; Nazemi, A.H.; Stuyt, L.C. Daily reference evapotranspiration modeling by using genetic programming approach in the Basque Country (Northern Spain). J. Hydrol. 2012, 414, 302-316. [CrossRef]

3. Parasuraman, K.; Elshorbagy, A.; Carey, S.K. Modelling the dynamics of the evapotranspiration process using genetic programming. Hydrol. Sci. J. 2007, 52, 563-578. [CrossRef]

4. Mehr, A.D. An improved gene expression programming model for streamflow forecasting in intermittent streams. J. Hydrol. 2018, 563, 669-678. [CrossRef]

5. Mehr, A.D.; Nourani, V. A Pareto-optimal moving average-multigene genetic programming model for rainfall-runoff modelling. Environ. Model. Softw. 2017, 92, 239-251. [CrossRef]

6. Babovic, V.; Keijzer, M. Rainfall runoff modeling based on genetic programming. Nord. Hydrol. 2002, 33, 331-343. [CrossRef]

7. Liong, S.Y.; Gautam, T.R.; Khu, S.T.; Babovic, V.; Keijzer, M.; Muttil, N. Genetic programming: A new paradigm in rainfall runoff modeling. J. Am. Water Res. Assoc. 2002, 38, 705-718. [CrossRef]

8. Aytek, A.; Alp, M. An application of artificial intelligence for rainfall runoff modeling. J. Earth Syst. Sci. 2008, 117, 145-155. [CrossRef]

9. Aytek, A.; Kisi, O. A genetic programming approach to suspended sediment modeling. J. Hydrol. 2008, 351, 288-298. [CrossRef]

10. Harris, E.L.; Babovic, V.; Falconer, R.A. Velocity predictions in compound channels with vegetated flood plains using genetic programming. Int. J. River Basin Manag. 2003, 1, 117-123. [CrossRef]

11. Babovic, V.; Drecourt, J.P.; Keijzer, M.; Hansen, P.F. A data mining approach to modeling of water supply assets. Urban Water 2002, 4, 401-414. [CrossRef]

12. Terzi, O.; Keskin, M.E. Evaporation estimation using gene expression programming. J. Appl. Sci. 2005, 5, 508-512.

13. Irmak, A.; Kamble, B. Evapotranspiration data assimilation with genetic algorithms and SWAP model for on-demand irrigation. Irrig. Sci. 2009, 28, 101-112. [CrossRef]

14. Traore, S.; Guven, A. Regional-specific numerical models of evapotranspiration using gene-expression programming interface in Sahel. Water Resour. Manag. 2012, 26, 4367-4380. [CrossRef]

15. Shiri, J. Evaluation of FAO56-PM, empirical, semi-empirical and gene expression programming approaches for estimating daily reference evapotranspiration in hyper-arid regions of Iran. Agric. Water Manag. 2017, 188, 101-114. [CrossRef]

16. Traore, S.; Luo, Y.; Fipps, G. Gene-expression programming for short-term forecasting of daily reference evapotranspiration using public weather forecast information. Water Resour. Manag. 2017, 31, 4891-4908. [CrossRef]

17. Mattar, M.A. Using gene expression programming in monthly reference evapotranspiration modeling: A case study in Egypt. Agric. Water Manag. 2018, 198, 28-38. [CrossRef]

18. Kim, S.; Kim, H.S. Neural networks and genetic algorithm approach for nonlinear evaporation and evapotranspiration modeling. J. Hydrol. 2008, 351, 299-317. [CrossRef]

19. Izadifar, Z.; Elshorbagy, A. Prediction of hourly actual evapotranspiration using neural networks, genetic programming, and statistical models. Hydrol. Process. 2010, 24, 3413-3425. [CrossRef]

20. Kisi, O.; Guven, A. Evapotranspiration modeling using linear genetic programming technique. J. Irrig. Drain. Eng. 2010, 136, 715-723. [CrossRef]

21. Eslamian, S.S.; Gohari, S.A.; Zareian, M.J.; Firoozfar, A. Estimating Penman-Monteith reference evapotranspiration using artificial neural networks and genetic algorithm: A case study. Arab. J. Sci. Eng. 2012, 37, 935-944. [CrossRef]

22. Wang, Y.; Guo, S.; Chen, H.; Zhou, Y. Comparative study of monthly inflow prediction methods for the Three Gorges Reservoir. Stoch. Environ. Res. Risk Assess. 2014, 28, 555-570. [CrossRef] 
23. Shiri, J.; Sadraddini, A.A.; Nazemi, A.H.; Kisi, O.; Marti, P.; Fard, A.F.; Landeras, G. Evaluation of different data management scenarios for estimating daily reference evapotranspiration. Hydrol. Res. 2013, 44, 1058-1070. [CrossRef]

24. Marti, P.; Gonzalez-Altozano, P.; Lopez-Urrea, R.; Mancha, L.A.; Shiri, J. Modeling reference evapotranspiration with calculated targets. Assessment and implications. Agric. Water Manag. 2015, 149, 81-90. [CrossRef]

25. Piri, H. Evaluation of computational methods for estimation of reference evapotranspiration with lysimeter data (case study: Sistan Plan). Water Irrig. 2012, 3, 50-62, (In Persian with English Abstract).

26. Pouryazdankhah, H.; Razavipour, T.; Khaledian, M.R.; Rezaei, M. Determination of proper methods to estimate reference evapotranspiration in Rasht. In Proceedings of the 3rd National Conferene on Comperehensive Water Resources Management, Sari, Iran, 10 September 2012; Available online: http: //www.civilica.com/Paper--NCUIMWR03--NCUIMWR03_115.html (accessed on 17 July 2012). (In Persian).

27. Razzaghi, F; Sepaskhah, A. Evaluation of different reference crop evapotranspiration methods using weithed lysimeter data. In Proceedings of the 9th Conference on Irrigation and Reduction of Evaporation, Kerman, Iran, 4-6 February 2007; Available online: http://www.civilica.com/Paper--ABYARI09--ABYARI09_029.html (accessed on 11 October 2007). (In Persian).

28. Rezaei, A.; Bakhtiari, B.; Houshyaripour, F.; Dehghani Anari, M. Evaluation of different estimation methods for reference evapotranspiration using lysimeter measurements. In Proceedings of the 9th Conference on Irrigation and Reduction of Evaporation, Kerman, Iran, 4-6 February 2007; Available online: http: //www.civilica.com/Paper--ABYARI09--ABYARI09_017.html (accessed on 11 October 2007). (In Persian).

29. Rezvani, S.V.A.; Fathi, P.; Khodamoradpour, M.; Azizpour, S. Evaluation and verification of computational equations of reference evapotranspiration in Sanandaj. In Proceedings of the 1st Conference on Applied Researches of Iran Water Resources, Kermanshah, Iran, 11 May 2010; Available online: http://www.civilica. com/Paper--INCWR01--INCWR01_073.html (accessed on 9 June 2010). (In Persian).

30. Shayannezhad, M. Comparison of accuracy of artificial neural networks and Penman-Monteith methods to estimate potential evapotranspiration. In Proceedings of the 1st National Conference on Management of Irrigation and Drainage Networks, Ahvaz, Iran, 25 August 2006; Available online: http:/www.civilica.com/ Paper--IDNC01--IDNC01_001.html (accessed on 3 September 2006). (In Persian).

31. Tafazoli, F.; Sabziparvar, A.A.; Zare Abyaneh, H.; Banzhad, H. Evaluation of conventional reference evapotranspiration models in cold and arid climate to optimal use of radiation models. In Proceedings of the 9th Conference on Irrigation and Reduction of Evaporation, Kerman, Iran, 4-6 February 2007; Available online: http://www.civilica.com/Paper--ABYARI09--ABYARI09_012.html (accessed on 11 October 2007). (In Persian).

32. Tanian, S.; Mirmasoudi, S.S.; Ghiami, F.; Zare Abyaneh, H. Evaluation of reference evapotranspiration using lysimeter data in Urmia. In Proceedings of the 2nd National Conference on Management of Irrigation and Drainage Networks, Ahvaz, Iran, 28-30 January 2008; Available online: http://www.civilica.com/Paper-IDNC02--IDNC02_277.html (accessed on 3 September 2008). (In Persian).

33. Vahidi, A. Evaluation of different estimation methods for reference evapotranspiration using weighed lysimeter. In Proceedings of the 10th Conference on Irrigation and Reduction of Evaporation, Kerman, Iran, 2-3 December 2009; Available online: http://www.civilica.com/Paper--ABYARI10--ABYARI10_197.html (accessed on 11 October 2009). (In Persian).

34. Zare Abyaneh, H.; Ghasemi, A.; Ahmadi, M. Determination of the most proper method to estimate reference crop evapotranspiration in comparison with empirical methods for Hamedan. In Proceedings of the 9th Conference on Irrigation and Reduction of Evaporation, Kerman, Iran, 4-6 February 2007; Available online: http://www.civilica.com/Paper--ABYARI09--ABYARI09_022.html (accessed on 11 October 2007). (In Persian).

35. Allen, R.G.; Pereira, L.S.; Raes, D.; Smith, M. Crop Evapotranspiration-Guidelines for Computing Crop Water Requirements_FAO Irrigation and Drainage Paper 56; FAO: Rome, Italy, 1998.

36. Hargreaves, G.L.; Samani, Z.A. Reference crop evapotranspiration from temperature. Appl. Eng. Agric. 1985, 1, 96-99. [CrossRef]

37. Jensen, M.E.; Haise, H.R. Estimation of evapotranspiration from solar radiation. J. Irrig. Drain. Div. 1963, 89, $15-41$.

38. WMO. Measurement and Estimation of Evaporation and Evapotranspiration; Tech. Pap. (CIMO-Rep) 83; Royal Meteorological Society: Geneva, Switzerland, 1966. 
39. Abtew, W. Evapotranspiration measurements and methoding for three wetland systems in South Florida. J. Am. Water Resour. Assoc. 1996, 32, 465-473. [CrossRef]

40. Makkink, G.F. Testing the Penman formula by means of lysimeters. J. Instit. Water Eng. 1957, 11, $277-288$.

41. Turc, L. Estimation of irrigation water requirements, potential evapotranspiration: A simple climatic formula evolved up to date. Ann. Agron. 1961, 12, 13-49.

42. Xu, C.Y.; Singh, V.P.; Chen, Y.D.; Chen, D. Evaporation and evapotranspiration. In Hydrology and Hydraulics, 1st ed.; Singh, V.P., Ed.; Water Resources Publications, LLC: Highlands Ranch, CO, USA, 2008; pp. 229-276.

43. Blaney, H.F.; Criddle, W.D. Determining Water Requirements in Irrigated Areas from Climatological and Irrigation Data; Soil Conservation Service Technical Paper 96; Soil Conservation Service, US Department of Agriculture: Washington, DC, USA, 1950.

44. Droogers, P.; Allen, R.G. Estimating reference evapotranspiration under inprecise data conditions. Irrig. Drain. Syst. 2002, 16, 33-45. [CrossRef]

45. Trajkovic, S. Hargreaves versus Penman-Monteith under Humid Condition. J. Irrig. Drain. Eng. 2007, 133, 38-42. [CrossRef]

46. Ahmadi, S.H.; Fooladmand, H.R. Spatially distributed monthly reference evapotranspiration derived from the calibration of Thornthwaite equation: A case study, South of Iran. Irrig. Sci. 2008, 26, 303-312. [CrossRef]

47. Almorox, J.; Quej, V.H.; Mari, P. Global performance ranking of temperature-based approaches for evapotranspiration estimation considering Köppen climate classes. J. Hydrol. 2015, 528, 514-522. [CrossRef]

48. Caporusso, N.B.; Rolim, G.D.S. Reference evapotranspiration models using different time scales in the Jaboticabal region of São Paulo, Brazil. Acta Sci. Agron. 2015, 37, 1-9. [CrossRef]

49. Heydari, M.M.; Tajamoli, A.; Ghoreishi, S.H.; Darbe-Esfahani, M.K.; Gilasi, H. Evaluation and calibration of Blaney-Criddle equation for estimating reference evapotranspiration in semiarid and arid regions. Environ. Earth Sci. 2015, 74, 4053-4063. [CrossRef]

50. Mallikarjuna, P.; Jyothy, S.A.; Murthy, D.S.; Reddy, K.C. Performance of recalibrated equations for the estimation of daily reference evapotranspiration. Water Resour. Manag. 2014, 28, 4513-4535. [CrossRef]

51. Ferreira, C. Gene Expression Programming Mathematical Modeling by an Artificial Intelligence; Studies in Computational Intelligence, 21; Springer: Berlin/Heidelberg, Germany, 2006; ISBN 978-3-540-32849-0.

52. Koza, J.R. Genetic Programming: On the Programming of Computers by Means of Natural Selection; The MIT Press: Cambridge, MA, USA, 1992.

53. Wang, L.; Kisi, O.; Hu, B.; Bilal, M.; Zounemat-Kermani, M.; Li, H. Evaporation modelling using different machine learning techniques. Int. J. Climatol. 2017, 37, 1076-1092. [CrossRef]

54. Wang, S.; Lian, J.; Peng, Y.; Hu, B.; Chen, H. Generalized reference evapotranspiration models with limited climatic data based on random forest and gene expression programming in Guangxi, China. Agric. Water Manag. 2019, 221, 220-230. [CrossRef]

55. Mehdizadeh, S. Estimation of daily reference evapotranspiration (ETo) using artificial intelligence methods: Offering a new approach for lagged ETo data-based modeling. J. Hydrol. 2018, 559, 794-812. [CrossRef]

(C) 2019 by the authors. Licensee MDPI, Basel, Switzerland. This article is an open access article distributed under the terms and conditions of the Creative Commons Attribution (CC BY) license (http://creativecommons.org/licenses/by/4.0/). 